\title{
Effluents Treatment Generated by Biolixiviation in the Extraction of Precious Metals through Selective Recovery of Iron, Copper and Zinc
}

\author{
Zambrano Johanna ${ }^{1}$, Zambrano Johnny ${ }^{2}$, * \\ ${ }^{1}$ Department of Chemical Engineering and Environmental Technology, University of Valladolid, Valladolid, Spain \\ ${ }^{2}$ Department of Petroleum, Escuela Politécnica Nacional, Quito, Ecuador
}

Email address:

vane_joan@hotmail.com (Z. Johanna), johnny.zambrano@epn.edu.ec (Z. Johnny)

${ }^{*}$ Corresponding author

\section{To cite this article:}

Zambrano Johanna, Zambrano Johnny. Effluents Treatment Generated by Biolixiviation in the Extraction of Precious Metals through Selective Recovery of Iron, Copper and Zinc. International Journal of Mineral Processing and Extractive Metallurgy.

Vol. 4, No. 2, 2019, pp. 44-50. doi: 10.11648/j.ijmpem.20190402.12

Received: July 16, 2019; Accepted: August 12, 2019; Published: September 2, 2019

\begin{abstract}
Bioleaching comprises the use of microorganisms for metal-extraction processes from sulphide ores. During these complex processes, sulphides are oxidized to sulphates with the generation of heat. As a result, gold, silver, and other precious metals are liberated from the sulphide matrix, improving their recovery after further processing. A drawback of bioleaching processes is the generation of significant amounts of acid solutions with high heavy metal concentrations. If untreated, these acid solutions may alter the physical and chemical characteristics of water and its surroundings, with high impact to aquatic ecosystems. High heavy metal concentrations in solution may also result in pollution to living organisms. A feasible method to treat bioleaching-generated solutions is selective precipitation. This investigation presents the conditions for a successful individual recovery of the main base metals contained in a bioleaching solution with high copper, zinc, and iron concentrations by $\mathrm{pH}$-based selective precipitation. Tests were made with standard solutions of known concentrations of copper, iron, lead and zinc and by titration the concentrations were checked; which allowed to validate the volumetric titration method. The selective precipitation of heavy metals was carried out in three phases using real acid main drainage and bioleaching solutions generated at the laboratory. The first phase in a $\mathrm{pH}$ range of 2 to 4 to recover iron; the second phase in a $\mathrm{pH}$ range of 4 to 6 to recover copper; and the third phase in a $\mathrm{pH}$ range of 6 to 10 to recover zinc. The selective precipitation allowed the heavy metals to be completely removed from the solution or to achieve concentrations below the maximum allowable limit to be discharged to a body of water or public sewer. Results portray that the variation of $\mathrm{pH}$ is an effective method, easy to use and not expensive, feasible to be used in the purification of waters that have been polluted with heavy metals.
\end{abstract}

Keywords: Bioleaching, Precious Metals, Selective Recovery, Effluent Treatment

\section{Introduction}

In Ecuador, large gold mining deposits have been discovered in the areas of Nambija and Ponce Enríquez, in addition to traditional mining activities in Zaruma and Portovelo areas [1]. From the exploitation of these deposits, artisanal and industrial mining activity is developed in the south of the country, generating large investments, especially from foreign countries, and changes in mining legislation [2-4].

In these mining districts, the gold deposits also contain metal sulfides such as pyrite, chalcopyrite, arsenopyrite, galena and sphalerite, and when exposed to the action of air and water they undergo throw a series of physical, chemical and biological phenomena. This produces the oxidation of sulphides to sulphates by the catalytic action of bacteria such as Thiobacillus Ferrooxidans, T. Thiooxidans, T. Sulfooxidans, and T. Thioparus, in addition to the production of sulfuric acid that dissolves heavy metals such as iron, copper and zinc; process called bioleaching [5]. These solutions, with a high level of acidity, $\mathrm{pH}$ around 2, are dragged by water currents or runoff, constituting a powerful water and soil pollutant [6]. 
The main sources producing acid solutions in mining operations are drainages from underground mines, runoff in open-pit mining and leachate from tailings and mining waste [7]. These acidic solutions, with a high content of heavy metals in solution, are called "acid mine drainage" (DAM) [8]; see Figure 1.

DAM contains heavy metals such as lead, mercury, iron, copper and zinc, which are toxic in small concentrations (LD10 for lead, $1470 \mu \mathrm{g} / \mathrm{kg}$, LD50 for mercury, 30-50 $\mathrm{mg} / \mathrm{kg}$, LD50 for iron, $600 \mathrm{mg} / \mathrm{kg}$; LD50 for copper, 50-500 $\mathrm{mg} / \mathrm{kg}$, and, LD50 for zinc, $180 \mathrm{mg} / \mathrm{kg}$ ) and tend to bioaccumulate. Drains with lead, mercury, iron and copper are very close to sulfur; they form bonds with enzymes through sulfur and inhibit enzymatic functions, causing harm to people. In addition, the ions of cadmium, copper, lead and mercury when joining cell membranes restrain transport processes through the cell wall $[9,10]$.

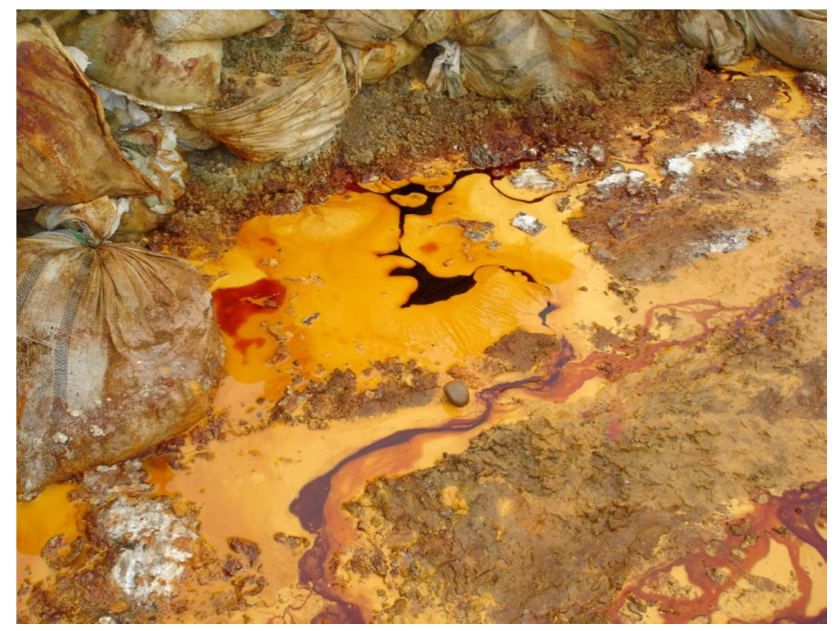

Figure 1. Acid mine drainage in piles of accumulated material, exposed to rain, humidity and high temperatures in the area (Ponce Enriquez mining district, Azuay province, Ecuador).

Globally, the mining industry faces one of the main problems of environmental pollution, acid mine drainages. In Ecuador, several of the mining deposits are located in areas of great biodiversity, which generates fragility and risk [1, 4]. These areas have rivers and lakes which at the same time are used for human consumption, agriculture and mining works; the inadequate management of tailings and sands that are discharged directly into rivers and streams generate serious damage to the environment $[11,12]$.

The aim of this study is to use selective precipitation, in order to recover iron, copper and zinc from acid solutions produced by bioleaching during the extraction of precious metals at a laboratory scale and from natural acid mine drainage, which will allow to comply with environmental regulations regarding to effluents discharge and to decrease the effect of environmental pollution generated by acid mine drainage $[13,14]$.

The results were obtained using volumetric analysis methods for the determination of $\mathrm{Fe}^{2+}, \mathrm{Fe}^{3+}$, total $\mathrm{Fe}, \mathrm{SO}_{4}{ }^{2-}$, $\mathrm{Cu}^{2+}$ and $\mathrm{Zn}^{2+}$ [15]. Bioleaching solutions were prepared with similar characteristics to the acid drainage of natural mines to carry out the tests of selective precipitation of heavy metals in solution. Pure metal hydroxides were precipitated from natural acid main drainage and form the bioleaching solutions generated under controlled processes in the laboratory [16]. Results show that the process proposed in the present study for iron, copper and zinc recovery has a potential industrial application.

\section{Methodology}

\subsection{Determination of Precipitation $\mathrm{pH}$}

The product of solubility (Ks) makes it possible to calculate the $\mathrm{pH}$ value at which the precipitation of a hydroxide begins and ends.

For copper hydroxide, after dissociation, the Ks and the hydroxide concentration $[\mathrm{OH}]$ are calculated [17]:

$$
\begin{gathered}
\mathrm{CuSO}_{4}+2 \mathrm{NaOH} \rightarrow \mathrm{Cu}(\mathrm{OH})_{2}+\mathrm{Na}_{2} \mathrm{SO}_{4} \\
\mathrm{Cu}(\mathrm{OH})_{2} \rightarrow \mathrm{Cu}^{2+}+2[\mathrm{OH}]^{-} \\
\mathrm{Ks}=\left[\mathrm{Cu}^{2+}\right]\left[\mathrm{OH}^{-}\right]^{2}=2.2 \times 10^{-20} \\
{[\mathrm{OH}]=\sqrt[2]{\frac{\mathrm{K}_{\mathrm{s}}}{\left[\mathrm{Cu}^{2+}\right]}}}
\end{gathered}
$$

With (4) the $\mathrm{pH}$ is plotted against the concentration of copper in solution. In Figure 2 the $\mathrm{pH}$ where the precipitation of copper hydroxide starts depending on the concentration of copper in solution is determined.

Similarly, for iron hydroxide:

$$
\begin{gathered}
\mathrm{Fe}_{2}\left(\mathrm{SO}_{4}\right)_{3}+6 \mathrm{NaOH} \rightarrow 2 \mathrm{Fe}(\mathrm{OH})_{3}+3 \mathrm{Na}_{2} \mathrm{SO}_{4} \\
\mathrm{Fe}(\mathrm{OH})_{3} \rightarrow \mathrm{Fe}^{3+}+3[\mathrm{OH}]^{-} \\
\mathrm{Ks}=\left[\mathrm{Fe}^{3+}\right]\left[\mathrm{OH}^{-}\right]^{3}=4.0 \times 10^{-38} \\
{[\mathrm{OH}]=\sqrt[3]{\frac{\mathrm{K}_{\mathrm{s}}}{\left[\mathrm{Fe}^{3+}\right]}}}
\end{gathered}
$$

With (9) the $\mathrm{pH}$ is plotted against the concentration of iron in solution. In Figure 3 the $\mathrm{pH}$ where the precipitation of iron hydroxide starts as a function of the concentration of iron in solution is determined.

And, for zinc hydroxide:

$$
\begin{gathered}
\mathrm{ZnSO}_{4}+2 \mathrm{NaOH} \rightarrow \mathrm{Zn}(\mathrm{OH})_{2}+\mathrm{Na}_{2} \mathrm{SO}_{4} \\
\mathrm{Zn}(\mathrm{OH})_{2} \rightarrow \mathrm{Zn}^{2+}+2[\mathrm{OH}]^{-} \\
\mathrm{Ks}=\left[\mathrm{Zn}^{2+}\right]\left[\mathrm{OH}^{-}\right]^{2}=1.8 \times 10^{-14} \\
{[\mathrm{OH}]=\sqrt[2]{\frac{\mathrm{K}_{\mathrm{s}}}{\left[\mathrm{Zn}^{2+}\right]}}}
\end{gathered}
$$

With (12) the $\mathrm{pH}$ is plotted against zinc concentration in solution. In Figure 4 the $\mathrm{pH}$ where the precipitation of zinc hydroxide starts depending on the concentration of zinc in solution is determined. 


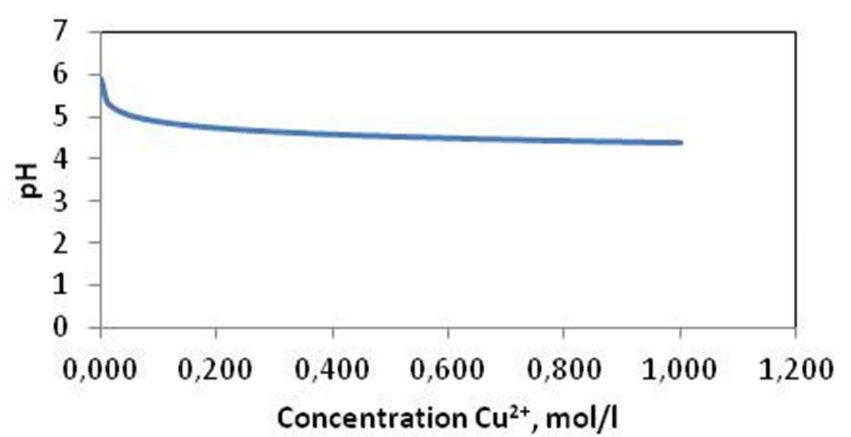

Figure 2. $p H$ at which the precipitation of copper hydroxide starts depending on the concentration of copper in solution.

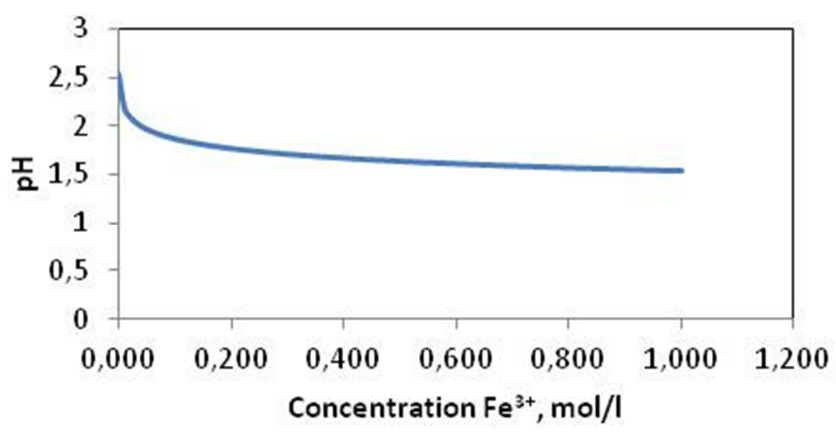

Figure 3. $\mathrm{pH}$ at which the precipitation of iron hydroxide starts depending on the concentration of iron in solution.

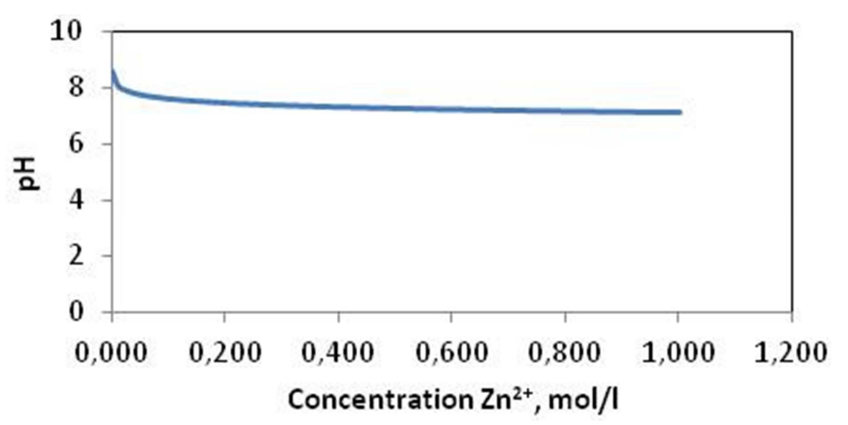

Figure 4. $p H$ at which the precipitation of zinc hydroxide starts depending on the concentration of zinc in solution.

\subsection{Experimental Procedure}

Validation of analysis methods. Volumetric methods were validated as analytical methods for the determination of $\mathrm{Fe}^{2+}$, $\mathrm{Fe}^{3+}$, total $\mathrm{Fe}, \mathrm{SO}_{4}{ }^{2-}, \mathrm{Cu}^{2+}$ and $\mathrm{Zn}^{2+}$ [15]. Additionally, tests were performed to demonstrate that there is no interference between the ions to be analyzed.

Sampling. Samples of gold ore and acid mine drainage (DAM) were collected in the Ponce Enríquez mining district, Province of Azuay [18]. In the area, accumulated piles of material are located for years that due to high temperatures and constant rains generate large amounts of acid mine drainage.

Table 1. Composition of K9 Medium for 1 liter of Solution.

\begin{tabular}{llllllll}
\hline Volume (l) & $\mathrm{FeSO}_{4} \cdot \mathbf{7} \mathrm{H}_{2} \mathrm{O}(\mathrm{g})$ & $\left(\mathrm{NH}_{4}\right)_{2} \mathbf{S O}_{4}(\mathrm{~g})$ & $\mathrm{KH}_{2} \mathrm{PO}_{4}(\mathrm{~g})$ & $\mathbf{H}_{3} \mathrm{PO}_{4}(\mathrm{~g})$ & $\mathrm{MgSO}_{4}(\mathrm{~g})$ & $\mathbf{G l u c o s e}(\mathrm{g})$ & $\mathbf{H}_{2} \mathrm{SO}_{4}(\mathrm{~g})$ \\
\hline 1 & 9 & 2.71 & 0.38 & 0.78 & 0.38 & 10 & 3.03 \\
\hline
\end{tabular}

Leaching test. Bioleaching tests were conducted in four tanks with agitation and continuous aeration for six months. Each of the tanks contained acid drainage from a natural mine, K9 nutrient medium, gold ore and sulfuric acid to maintain a low $\mathrm{pH}$. In Table 1 characteristics of the nutrient medium K9 are shown. In addition, brown sugar and ethanol were added to the first tank. During the six months of tests, periodic analyzes of $\mathrm{Fe}^{2+}, \mathrm{Fe}^{3+}$, total $\mathrm{Fe}, \mathrm{SO}_{4}{ }^{2-}, \mathrm{Cu}^{2+}$ and $\mathrm{Zn}^{2+}$ were done.

Samples characterization. The methods to characterize the samples were: method for the determination of $\mathrm{Fe}^{2+}$ in solution, method for the determination of $\mathrm{SO}_{4}{ }^{2-}$ in solution and atomic absorption, with hydrochloric acid matrix [19]. The characterized samples were:

Orenas bioleaching solution: the piles of accumulated material in Orenas, Ponce Enríquez mining district, exposed to rain, humidity and high temperatures, generate leachates of acid solutions. To these leachate samples of acid solutions, nutrients were added to stimulate the generation of bacteria; these solutions were used for bioleaching tests.

Bioleaching solution SOLBIO 1: product of bioleaching tests carried out in laboratory. To generate the solution, acid drainage from natural mine, K9 nutrient medium, brown suggar, ethanol, hydrogen peroxide, mineral from Ponce Enríquez mining district and sulfuric acid were used to maintain a $\mathrm{pH}$ of 2 .

Bioleaching solution SOLBIO 2: product of bioleaching tests carried out in laboratory. To generate the solution, acid drainage from natural mine, K9 nutrient medium, hydrogen peroxide, mineral from Ponce Enríquez mining district and sulfuric acid were used to maintain a $\mathrm{pH}$ of 2 .

Selective precipitation tests. For the selective precipitation of iron, copper and zinc, from the bioleaching solutions Orenas, SOLBIO 1 and SOLBIO 2, prepared with acid drainage from natural ore and gold ore, six different tests were performed. Each test follows a logical order for the sequential separation (by stages) of heavy metals and, by means of atomic absorption method, both for the filtrates and for the precipitates (partial and final precipitates), the percentages of recovery were determined.

\section{Results and Discussion}

Validation of analysis methods. Results of the validation of the analysis methods in Tables 2-5. It was verified that it is possible to determine the presence of copper, iron, lead and zinc in a solution without interference between the ions to be analyzed. The metal solutions were prepared with lead acetate and with copper, iron and zinc sulfates. 
Table 2. Validation of Analysis Methods in Individual Metal Solutions.

\begin{tabular}{llllll}
\hline \multirow{2}{*}{ Ion } & $\mathrm{KMnO}_{4}$ & & $\mathbf{N a}_{2} \mathbf{S}_{2} \mathbf{O}_{3}$ & & Interference \\
\cline { 2 - 5 } & Expected & Obtained & Expected & Obtained & Yes \\
\hline $\mathrm{Fe}^{2+}$ & $5.0 \mathrm{ml}$ & $5.0 \mathrm{ml}$ & & $\mathrm{N}$ \\
$\mathrm{Fe}^{3+}$ & $5.0 \mathrm{ml}$ & $5.2 \mathrm{ml}$ & $1.6 \mathrm{ml}$ & $\mathrm{X}$ \\
$\mathrm{Cu}^{2+}$ & & & $1.5 \mathrm{ml}$ & $\mathrm{X}$ \\
$\mathrm{Zn}^{2+}$ & $9.0 \mathrm{ml}$ & $9.0 \mathrm{ml}$ & $15 \mathrm{ml}$ & $\mathbf{X}$ \\
$\mathrm{Pb}^{2+}$ & & & & $15 \mathrm{ml}$ & $\mathrm{X}$ \\
\hline
\end{tabular}

Table 3. Validation of Analysis Methods in Binary Metal Solutions.

\begin{tabular}{|c|c|c|c|c|c|c|}
\hline \multirow{2}{*}{ Ion } & \multirow{2}{*}{$\begin{array}{l}\mathrm{KMnO}_{4} \\
\text { Expected } \\
\end{array}$} & \multirow[b]{2}{*}{ Obtained } & \multicolumn{2}{|l|}{$\mathrm{Na}_{2} \mathrm{~S}_{2} \mathrm{O}_{3}$} & \multicolumn{2}{|c|}{ Interference } \\
\hline & & & Expected & Expected & Yes & No \\
\hline $\mathrm{Fe}^{2+} \& \mathrm{Fe}^{3+}$ & $\begin{array}{l}2.5 \mathrm{ml} \\
5.0 \mathrm{ml}\end{array}$ & $\begin{array}{l}2.6 \mathrm{ml} \\
5.2 \mathrm{ml}\end{array}$ & & & & $X$ \\
\hline $\mathrm{Fe}^{2+} \& \mathrm{Cu}^{2+}$ & $2.5 \mathrm{ml}$ & $2.5 \mathrm{ml}$ & $0.8 \mathrm{ml}$ & $0.7 \mathrm{ml}$ & & $\mathrm{X}$ \\
\hline $\mathrm{Fe}^{2+} \& \mathrm{Zn}^{2+}$ & $\begin{array}{l}2.5 \mathrm{ml} \\
9.5 \mathrm{ml}\end{array}$ & $\begin{array}{l}2.6 \mathrm{ml} \\
9.6 \mathrm{ml}\end{array}$ & & & & $X$ \\
\hline $\mathrm{Fe}^{3+} \& \mathrm{Cu}^{2+}$ & $2.5 \mathrm{ml}$ & $2.7 \mathrm{ml}$ & $0.8 \mathrm{ml}$ & $0.8 \mathrm{ml}$ & & $\mathrm{X}$ \\
\hline $\mathrm{Fe}^{3+} \& \mathrm{Zn}^{2+}$ & $\begin{array}{l}2.5 \mathrm{ml} \\
9.5 \mathrm{ml}\end{array}$ & $\begin{array}{l}2.5 \mathrm{ml} \\
9.4 \mathrm{ml}\end{array}$ & & & & $X$ \\
\hline $\mathrm{Cu}^{2+} \& \mathrm{Zn}^{2+}$ & $9.5 \mathrm{ml}$ & $9.4 \mathrm{ml}$ & $0.8 \mathrm{ml}$ & $0.7 \mathrm{ml}$ & & $\mathrm{X}$ \\
\hline
\end{tabular}

Table 4. Validation of Analysis Methods in Tertiary Metal Solutions.

\begin{tabular}{|c|c|c|c|c|c|c|}
\hline \multirow{2}{*}{ Ion } & \multicolumn{2}{|l|}{$\mathrm{KMnO}_{4}$} & \multicolumn{2}{|l|}{$\mathrm{Na}_{2} \mathrm{~S}_{2} \mathrm{O}_{3}$} & \multicolumn{2}{|c|}{ Interference } \\
\hline & Expected & Obtained & Expected & Expected & Yes & No \\
\hline & $1.7 \mathrm{ml}$ & $1.7 \mathrm{ml}$ & & & & \\
\hline $\mathrm{Fe}^{2+}, \mathrm{Fe}^{3+} \& \mathrm{Zn}^{2+}$ & $3.3 \mathrm{ml}$ & $3.4 \mathrm{ml}$ & & & & $\mathrm{X}$ \\
\hline & $9.7 \mathrm{ml}$ & $9.7 \mathrm{ml}$ & & & & \\
\hline $\mathrm{Fe}^{2+}, \mathrm{Fe}^{3+} \& \mathrm{Cu}^{2+}$ & $\begin{array}{l}1.7 \mathrm{ml} \\
3.3 \mathrm{ml}\end{array}$ & $\begin{array}{l}1.7 \mathrm{ml} \\
3.3 \mathrm{ml}\end{array}$ & $0.5 \mathrm{ml}$ & $0.5 \mathrm{ml}$ & & $\mathrm{X}$ \\
\hline $\mathrm{Fe}^{2+}, \mathrm{Cu}^{2+} \& \mathrm{Zn}^{2+}$ & $\begin{array}{l}1.7 \mathrm{ml} \\
0.5 \mathrm{ml}\end{array}$ & $\begin{array}{l}1.9 \mathrm{ml} \\
0.4 \mathrm{ml}\end{array}$ & $9.7 \mathrm{ml}$ & $9.8 \mathrm{ml}$ & & $\mathrm{X}$ \\
\hline $\mathrm{Fe}^{3+}, \mathrm{Cu}^{2+} \& \mathrm{Zn}^{2+}$ & $\begin{array}{l}1.7 \mathrm{ml} \\
0.5 \mathrm{ml}\end{array}$ & $\begin{array}{l}1.8 \mathrm{ml} \\
0.5 \mathrm{ml}\end{array}$ & $9.7 \mathrm{ml}$ & $9.7 \mathrm{ml}$ & & $\mathrm{X}$ \\
\hline
\end{tabular}

Table 5. Validation of Methods of Analysis in Quaternary Metal Solutions.

\begin{tabular}{|c|c|c|c|c|c|c|}
\hline \multirow{2}{*}{ Ion } & \multicolumn{2}{|l|}{$\mathrm{KMnO}_{4}$} & \multicolumn{2}{|l|}{$\mathrm{Na}_{2} \mathrm{~S}_{2} \mathrm{O}_{3}$} & \multicolumn{2}{|c|}{ Interference } \\
\hline & Expected & Obtained & Expected & Expected & Yes & No \\
\hline $\mathrm{Fe}^{2+}, \mathrm{Fe}^{3+}, \mathrm{Cu}^{2+} \& \mathrm{Zn}^{2+}$ & $\begin{array}{l}1.3 \mathrm{ml} \\
2.5 \mathrm{ml} \\
9.8 \mathrm{ml}\end{array}$ & $\begin{array}{l}1.3 \mathrm{ml} \\
2.5 \mathrm{ml} \\
9.9 \mathrm{ml}\end{array}$ & $0.4 \mathrm{ml}$ & $0.3 \mathrm{ml}$ & & $\mathrm{X}$ \\
\hline
\end{tabular}

Samples characterization. Results of the characterization of the three samples of bioleaching solutions in Table 6 . The characteristics of the solutions generated by a controlled bioleaching process in the laboratory are similar to those of the natural bioleaching solution, Orenas.

Results show that iron is the predominant component of the solutions, but it was found as $\mathrm{Fe}^{2+}$ and $\mathrm{Fe}^{3+}$. As the precipitation $\mathrm{pH}$ of $\mathrm{Fe}^{2+}$ is very close to the precipitation $\mathrm{pH}$ of $\mathrm{Cu}^{2+}$, an oxidant was used to oxidice $\mathrm{Fe}^{2+}$ to $\mathrm{Fe}^{3+}$ and allow the range of precipitation between copper and iron to be wider.

Table 6. Solutions characteristics.

\begin{tabular}{|c|c|c|c|c|c|c|c|c|}
\hline $\begin{array}{l}\text { Solution } \\
\text { (Bioleaching) }\end{array}$ & Initial pH & Volume (I) & Sulfates (g/l) & $\mathrm{Fe}^{2+}(\mathrm{mg} / \mathrm{l})$ & $\mathrm{Fe}^{3+}(\mathrm{mg} / \mathrm{l})$ & $\begin{array}{l}\text { Total Fe } \\
(\mathrm{mg} / \mathrm{l})\end{array}$ & $\begin{array}{l}\text { Copper } \\
(\mathrm{mg} / \mathrm{l})\end{array}$ & $\begin{array}{l}\text { Zinc } \\
(\mathrm{mg} / \mathrm{l})\end{array}$ \\
\hline Orenas & 1.92 & 14 & 60.98 & 55.84 & 12660.2 & 12716 & 108.8 & 464.0 \\
\hline SOLBIO 1 & 1.68 & 14 & 54.35 & 1563.52 & 10290.5 & 11854 & 71.8 & 301.2 \\
\hline SOLBIO 2 & 2.54 & 14 & 53.89 & 1072.13 & 9323.9 & 10396 & 108.4 & 381.8 \\
\hline
\end{tabular}

Selective precipitation tests

First test. In $250 \mathrm{ml}$ of SOLBIO 2 bioleaching solution, 25 $\mathrm{ml}$ of $1 \mathrm{M} \mathrm{NaOH}$ was added to have a $\mathrm{pH}$ variation of 2.46 to 3.54; under these conditions, precipitate 1 was obtained and $10 \mathrm{ml}$ of $\mathrm{H}_{2} \mathrm{O}_{2}$ was added to the filtrate to obtain precipitate two.
The presence of $\mathrm{H}_{2} \mathrm{O}_{2}$ caused the $\mathrm{pH}$ of the solution to drop, allowing a third precipitation to be made by varying the $\mathrm{pH}$ from 2.69 to 3.6 by the addition of $47 \mathrm{ml}$ of $1 \mathrm{M}$ $\mathrm{NaOH}$. Finally, the three precipitates were filtered and analyzed by atomic absorption method. In this first stage removals of $99.76,24.83$ and $10.99 \%$ were obtained for iron, 
copper and zinc, respectively.

The filtered solution was subjected to precipitation by adding $9.5 \mathrm{ml}$ of $1 \mathrm{M} \mathrm{NaOH}$ obtaining a $\mathrm{pH}$ variation of 4.5 to 6 . The solution was filtered and the precipitate was analyzed by atomic absorption method. In this second stage, iron was removed in $100 \%$, copper in $96.51 \%$ and zinc in $18.56 \%$.

The third stage consisted in vary the $\mathrm{pH}$ of the filtered solution from 7.54 to 9 by adding $2.7 \mathrm{ml}$ of $1 \mathrm{M} \mathrm{NaOH}$, to obtain a final precipitate and leave the solution free of heavy metals. This stage allowed $100 \%$ copper and $99.95 \%$ zinc recovering.

Second test. In $250 \mathrm{ml}$ of SOLBIO 2 bioleaching solution, $39.7 \mathrm{ml}$ of $1 \mathrm{M} \mathrm{NaOH}$ was added to have a $\mathrm{pH}$ variation of 2.48 to 3.5 , and $10 \mathrm{ml}$ of $\mathrm{H}_{2} \mathrm{O}_{2}$ was added directly to obtain the first precipitate. The solution was filtered and the precipitate was analyzed. In this first stage, iron removal of $74.78 \%$, copper of $12.29 \%$ and zinc of $17.02 \%$ was obtained.

The presence of $\mathrm{H}_{2} \mathrm{O}_{2}$ caused the solution $\mathrm{pH}$ to drop, allowing a second precipitation to be made by varying the $\mathrm{pH}$ from 2.5 to 3.62 by the addition of $29.8 \mathrm{ml}$ of $1 \mathrm{M} \mathrm{NaOH}$. The solution was filtered and the precipitate was analyzed. In this second stage, iron was removed in $83.73 \%$, copper in $3.43 \%$ and zinc in $2.08 \%$.

As high levels of co-precipitation between copper and zinc were observed, $90.7 \mathrm{ml}$ of $1 \mathrm{M} \mathrm{NaOH}$ was added to the filtered solution to generate a $\mathrm{pH}$ rise of 4.18 to 13 . At $\mathrm{pH} 13$ all the copper precipitates and the zinc dissolves in the solution. The solution was filtered and the precipitate was analyzed. In this third stage recoveries of $98.75,67.36$ and $86.58 \%$ were obtained for iron, copper and zinc, respectively.

In the fourth stage, to precipitate zinc, the $\mathrm{pH}$ was lowered to 5.6 with the addition of $23.5 \mathrm{ml}$ of $1 \mathrm{M} \mathrm{H} \mathrm{H}_{2} \mathrm{SO}_{4}$. Subsequently, the solution $\mathrm{pH}$ was varied from 5.6 to 9.28 by the addition of $2.7 \mathrm{ml}$ of $1 \mathrm{M} \mathrm{NaOH}$, to obtain a final precipitate and leave the solution partially free of heavy metals. The solution was filtered and the precipitate was analyzed. In this stage, $41.77 \%$ iron, $88.46 \%$ copper and $89.54 \%$ zinc were recovered.

Current results show that raising the $\mathrm{pH}$ to precipitate copper and zinc together, so that zinc is redissolved simultaneously, is not viable to avoid co-precipitation; in the following tests this step was not used.

Third test. In $250 \mathrm{ml}$ of SOLBIO 1 bioleaching solution, $76.5 \mathrm{ml}$ of $1 \mathrm{M} \mathrm{NaOH}$ was added to have a $\mathrm{pH}$ variation of 2.32 to 3.62 . The solution was filtered and the precipitate was analyzed by atomic absorption method. In this first stage removals of $17.14,16.77$ and $7.12 \%$ were obtained for iron, copper and zinc, respectively.

To the filtered solution $10 \mathrm{ml}$ of $\mathrm{H}_{2} \mathrm{O}_{2}$ were added to obtain a second precipitate. The solution was filtered and the precipitate was analyzed. In this second stage iron was removed in $17.73 \%$, copper in $5.43 \%$ and zinc in $0.23 \%$. The presence of $\mathrm{H}_{2} \mathrm{O}_{2}$ caused a drop in the solution $\mathrm{pH}$. In order to obtain a third precipitation, the $\mathrm{pH}$ was varied from 2.3 to 3.61 by the addition of $69.7 \mathrm{ml}$ of $1 \mathrm{M} \mathrm{NaOH}$. The solution was filtered and the precipitate was analyzed. In this third stage, iron was removed in $97.73 \%$, copper in $16.78 \%$ and zinc in $8.22 \%$.

To the last filtered solution, $16.7 \mathrm{ml}$ of $1 \mathrm{M} \mathrm{NaOH}$ was added to have a $\mathrm{pH}$ variation of 4.12 to 6 and a fourth precipitate was obtained. The solution was filtered and the precipitate was analyzed. In this fourth stage, iron was removed in $100 \%$, copper in $91.06 \%$ and zinc in $44.63 \%$.

The fifth stage was to vary the $\mathrm{pH}$ of the filtered solution from 8 to 9.05 by adding $2.4 \mathrm{ml}$ of $1 \mathrm{M} \mathrm{NaOH}$ to obtain the final precipitate and leave the solution free form heavy metal. The solution was filtered and the precipitate was analyzed. In this stage copper was recovered in $84.96 \%$ and zinc in $100 \%$.

The test shows that each stage to recover iron is necessary. The first three precipitations present a significant contribution and cannot be omitted. However, coprecipitation is high, so in order to decrease co-precipitation, in the following tests, flocculants were used after each precipitation to increase metal removal.

Forth test. In $250 \mathrm{ml}$ of SOLBIO 1 bioleaching solution, $79.5 \mathrm{ml}$ of $1 \mathrm{M} \mathrm{NaOH}$ was added to have a $\mathrm{pH}$ variation of 2.28 to 3.8. The solution was filtered and the precipitate was analyzed. In this first stage iron was removed in $7.34 \%$, copper in $46.55 \%$ and zinc in $26.27 \%$. To this first filtrate, 1 $\mathrm{g} / \mathrm{l}$ of flocculant was added and stirred for half an hour. The solution was filtered and the filtrate was analyzed. By mass balance the mass composition of the metals present in the precipitate was determined and it was obtained that the coagulation allowed $0.08 \%$ iron, $8.13 \%$ copper and $45.85 \%$ zinc removal.

$10 \mathrm{ml}$ of $\mathrm{H}_{2} \mathrm{O}_{2}$ was added to the filtered solution and a third precipitate was obtained. The solution was filtered and the precipitate was analyzed. At this stage of the test, iron was removed in $24.21 \%$, copper in $10.24 \%$ and zinc in $20.68 \% .1 \mathrm{~g} / \mathrm{L}$ of flocculant was added to the filtered solution and stirred for half an hour. The solution was filtered and the filtrate was analyzed. By mass balance the mass composition of the metals present in the precipitate were determined and it was obtained that the coagulation allowed $51.58 \%$ iron, $4.81 \%$ copper and $0 \%$ zinc removal.

The presence of $\mathrm{H}_{2} \mathrm{O}_{2}$ caused the solution $\mathrm{pH}$ to drop, allowing a fifth precipitation to be made by varying the $\mathrm{pH}$ from 2.28 to 3.38 by the addition of $59.4 \mathrm{ml}$ of $1 \mathrm{M} \mathrm{NaOH}$. The solution was filtered and the precipitate was analyzed. This stage of the test allowed to remove iron in $97.13 \%$, copper in $56.52 \%$ and zinc in $8.42 \%$.

To the last filtered solution $1.2 \mathrm{ml}$ of $1 \mathrm{M} \mathrm{NaOH}$ was added for a $\mathrm{pH}$ variation of 5 to 6.06 . The solution was filtered and the precipitate was analyzed. The removals obtained were $37.33 \%$ for iron, $90.22 \%$ for cooper and $57.31 \%$ for zinc. $1 \mathrm{~g} /$ $\mathrm{L}$ of flocculant was added to the filtered solution and stirred for half an hour. The solution was filtered and the filtrate was analyzed. By mass balance the mass composition of the metals present in the precipitate were determined and it was obtained that the coagulation allowed to remove iron in $1.28 \%$, copper in $5.88 \%$ and zinc in $0 \%$. 
In the last stage the $\mathrm{pH}$ of the filtered solution was varied from 7.5 to 9 by the addition of $2 \mathrm{ml}$ of $1 \mathrm{M} \mathrm{NaOH}$, to obtain a final precipitate and leave the solution partially free of heavy metals. The solution was filtered and the precipitate was analyzed. Iron was recovered in $90.18 \%$, copper in $100 \%$ and zinc in $88.42 \%$.

Results showed that the use of flocculant improved the removal of heavy metals but it did not prevent coprecipitation. Therefore, considering that the use of flocculants did not help to improve the global recovery of iron, copper and zinc, its use was not considered in the following tests.

Fifth test. In the third test the contributions of the first three stages of the test were verified, and it could be seen that the first filtration could be omitted. In this test, $77.5 \mathrm{ml}$ of $1 \mathrm{M} \mathrm{NaOH}$ was added in $250 \mathrm{ml}$ of SOLBIO 1 bioleaching solution, obtaining a $\mathrm{pH}$ variation of 2.34 to 3.56, additionally $10 \mathrm{ml}$ of $\mathrm{H}_{2} \mathrm{O}_{2}$ is added directly to obtain the first precipitate. The solution was filtered and the precipitate was analyzed. In this first stage iron was removed in $49.72 \%$, copper in $9.08 \%$ and zinc in $8.92 \%$.

The presence of $\mathrm{H}_{2} \mathrm{O}_{2}$ caused the $\mathrm{pH}$ of the solution to drop, allowing a second precipitation to be performed by varying the $\mathrm{pH}$ from 2.28 to 3.51 by the addition of $55.9 \mathrm{ml}$ of $1 \mathrm{M} \mathrm{NaOH}$. The solution was filtered and the precipitate was analyzed. This second stage allowed to remove iron in $98.22 \%$, copper in $3.19 \%$ and zinc in $1.78 \%$.

To the filtered solution $20.5 \mathrm{ml}$ of $1 \mathrm{M} \mathrm{NaOH}$ was added verifying a $\mathrm{pH}$ variation of 4.15 to 6 . The solution was filtered and the precipitate was analyzed. Iron removal was $93.9 \%$, copper $92.37 \%$ and zinc $80.74 \%$.

In the last stage, the $\mathrm{pH}$ of the filtered solution was varied from 6.73 to 9 by the addition of $8.7 \mathrm{ml}$ of $1 \mathrm{M} \mathrm{NaOH}$, to obtain a final precipitate and leave the solution free of heavy metals. The solution was filtered and the precipitate was analyzed. Iron recovery was $7.28 \%$, copper $84.62 \%$ and zinc 95.78\%.

Sixth test. In $250 \mathrm{ml}$ of Orenas bioleaching solution, 150 $\mathrm{ml}$ of $1 \mathrm{M} \mathrm{NaOH}$ was added to have a $\mathrm{pH}$ variation of 2.4 to 3.08 , and $10 \mathrm{ml}$ of $\mathrm{H}_{2} \mathrm{O}_{2}$ was added directly to obtain the first precipitate. The solution was filtered and the precipitate analyzed; an iron removal of $78.58 \%$, copper of $13.31 \%$ and zinc of $7.43 \%$ was obtained.

The presence of $\mathrm{H}_{2} \mathrm{O}_{2}$ caused the $\mathrm{pH}$ of the solution to drop, allowing a second precipitation to be made by varying the $\mathrm{pH}$ from 3 to 3.52 by the addition of $18.3 \mathrm{ml}$ of $1 \mathrm{M}$ $\mathrm{NaOH}$. The solution was filtered and the precipitate was analyzed. This second stage of the test allowed to remove iron in $74.16 \%$, copper in $4.21 \%$ and zinc in $3.11 \%$. However, the filtrate still showed a highly turbid red color, evidencing the presence of iron in solution; therefore, it was decided to use a flocculant to improve the removal of heavy metals. $1 \mathrm{~g} / \mathrm{L}$ of flocculant was added to the filtered solution and stirred for half an hour.

The solution was filtered and the filtrate was analyzed. By mass balance the mass composition of the metals present in the precipitate was determined and it was obtained that the coagulation allowed to remove iron in $73.9 \%$, copper in $0 \%$ and zinc in $9.72 \%$.

To the filtered solution $35.9 \mathrm{ml}$ of $1 \mathrm{M} \mathrm{NaOH}$ was added and a $\mathrm{pH}$ variation of 3.98 to 6.28 was verified. The solution was filtered and the precipitate was analyzed. Iron removal was $96.11 \%$, copper $92.25 \%$ and zinc $94.97 \%$.

In the last stage of the test, the $\mathrm{pH}$ of the filtered solution was varied from 5.7 to 10 by the addition of $1.7 \mathrm{ml}$ of $1 \mathrm{M}$ $\mathrm{NaOH}$, to obtain a final precipitate and leave the solution free of heavy metals. The solution was filtered and the precipitate was analyzed. Iron was recovered in $63.33 \%$, copper in $36.67 \%$ and zinc in $100 \%$.

\section{Conclusions}

The validation of the methods of analysis allowed to demonstrate that the presence of copper, iron, lead and zinc in a solution can be determined by means of simple methods of analysis. The methods used are feasible to use in the field since only glass material and chemical reagents are needed.

The bioleaching tests showed that it is possible to generate solutions, with characteristics very similar to the acid drainage of natural mines, in a controlled manner in a laboratory. The bioleaching of the gold ore from Bella Rica using agitation, aeration, acid mine drainage, K9 nutrient medium, and a low $\mathrm{pH}$ showed that bacterial activity and an increase in heavy metals can occur over a period of six months. This process can be potentially used for industrial gold release processes associated with metal sulphides.

The selective precipitation of heavy metals was carried out in three phases. The first phase was carried out in a $\mathrm{pH}$ range of 2 to 4 to recover iron; the second phase was carried out in a $\mathrm{pH}$ range of 4 to 6 to recover copper; and the third phase was carried out in a $\mathrm{pH}$ range of 6 to 10 to recover zinc.

Coagulants and oxidants were used to improve the percentages of recovery and avoid co-precipitation. However, it was found that the use of coagulants did not help to avoid the co-precipitation of metals, and that the contribution to the percentages of recovery was negligible. On the other hand, the hydrogen peroxide used as a second step in the recovery process was very helpful in recovering iron, since it not only served to precipitate the metals but also lowered the $\mathrm{pH}$ of the solution allowing another precipitation process to be carried out within the $\mathrm{pH}$ range in which the iron precipitates.

All the selective precipitation tests carried out allowed the heavy metals to be completely eliminated from the solution or left at concentrations lower than the maximum permissible limit so that they can be discharged to a body of water or to the public sewage system. In this way it was proved that the variation of $\mathrm{pH}$ is an effective, easy to use and inexpensive method, feasible to be used in the purification of waters that have been polluted with heavy metals.

The percentages of heavy metals recovery were satisfactory; it was possible to remove most of the metal present in the solutions. However, co-precipitation could not be avoided; the metals precipitated in each phase did not 
come out pure. In the precipitation of iron there was selectivity, the percentages of iron recovery were higher than $97 \%$. In copper precipitation there was no selectivity, the other two metals were present in percentages higher than $10 \%$ and in some cases even exceed the percentage of copper recovered; it could be appreciated that at the moment in which copper was precipitated it dragged much of the zinc in solution. In the precipitation of zinc selectivity higher than $83 \%$ was achieved in most of the tests carried out.

The pretreatment of a refractory gold ore is established under technical considerations, environmental pollution, capital costs and operational risks. Bioleaching has advantages and disadvantages with respect to methods such as roasting or chemical leaching. The advantages of biolixiviation are the low capital and energy costs, in addition to the great flexibility to be used in situ and to be environmental friendly. Another great advantage is that due to the growth of Thiobacillus thiooxidans, the $\mathrm{pH}$ of the leached gradually decreases allowing a selective oxidation of sulfides. When used in the removal of soil contaminants, it reduces disposal costs and allows the recovery of precious metals.

\section{References}

[1] ARCOM, Agencia de Regulación y Control Minero, 2017. Catastro Minero. Access: http://www.controlminero.gob.ec/catastro-minero/.

[2] Hofner R., 2000. La minería artesanal hacia una minería en pequeña escala. Minería Ecuatoriana: 56-58.

[3] Ley de Minería, No 45, 2009. Registro Oficial Suplemento 517. Quito, Ecuador. 29 de enero de 2009.

[4] Ministerio de Minería, 2016. Plan nacional de desarrollo del sector minero. Quito, Ecuador.

[5] Villas Boas R., Sánchez M., 2006. Clean Technologies for the mining industry. CYTED: Rio de Janeiro, pp. 78-80.

[6] Barrie J., 2006. Biohydrometallurgy and the enviroment: Intimate and important interplay. Hydrometallurgy, 83, pp. 153-166.

[7] Córdoba E. M., Muñoz J. A., Blázquez M. L., González F., Ballester A., 2008. Leaching of chalcopyrite with ferric ions. Part II: effect of redox potential. Hydrometallurgy, 93, pp. 8896.
[8] LIFE-ETAD Project, 2016. Acid mine Drainage (AMD) in LIFE-ETAD Project, Ecological Treatment of Acid Drainge. Access: http://www.life-etad.com/index.php/es/drenajesacidos-de-minas-amd.

[9] FUNSAD, Fundación Salud Ambiente y Desarrollo, 2007. Impactos en el ambiente y la salud por la minería del oro a pequeña escala en el Ecuador (segunda fase): informe final.

[10] GAD CPE, Gobierno Autónomo Descentraluzado del Cantón Ponce Enriquez, 2017. Protección de Fuentes y Zonas de Recarga Hídrica, para las Captaciones de Agua para Consumo Humano. Registro Oficial No 07. Quito. Ecuador. 05 de junio de 2017.

[11] Durán W., Vásconez L., 2015. Evaluación ambiental de la cuenca del río Gala del cantón Ponce Enríquez. Universidad Politécnica Salesiana. Azuay. Ecuador.

[12] Moreno C., Chaparro E., 2009. Las leyes generales del ambiente y los códigos de la minería de los paises andinos. Instructivo de gestión ambiental y minero ambiental, CEPAL Naciones Unidas: Santiago de Chile, pp. 29-38.

[13] Ismael M., Carvalho J., 2003. Iron recovery from sulphate leach liquors in cinc hydrometallurgy, Minerals engineering, pp. 31-39.

[14] Langová S., Matýsek D., 2010. Cinc recovery from steelmaking wastes by acid pressure leaching and hematite precipitation, Hydrometallurgy, pp. 171-173.

[15] Ospina G., García de Ossa J., Martinez Yepes P., 2010. Gravimetría y Volumetría / Fundamentación Experimental en Química Analítica, Editorial Elizcom, pp. 150.

[16] He Z., Yin Z., Wang X., Zhong H., Sun W., 2012. Microbial community changes during the process of pyrite bioleaching. Hydrometallurgy, 125-126 (3), pp. 81-89.

[17] Levenspiel O., 2004. Ingeniería de las reacciones químicas. $3^{\text {a }}$ ed. México, Limusa Wiley, 669 pp.

[18] Sepúlveda V, T., Velasco T, J., De la Rosa P, D., 2005. Suelos contaminados por metales y metaloides: muestreo $\mathrm{y}$ alternativas para su remediación, Instituto Nacional de Ecología: México, pp. 99-101.

[19] Nurmi P., Özkaya B., Sasaki K., Kaksonen A. H., et al., 2009. Biooxidation and precipitation for iron and sulfate removal from heap bioleaching effluent streams, Hydrometallurgy, pp. 7-14. 